\title{
Phytotechnical parameters and yield of watermelon plants under different irrigation and nitrogen levels
}

\author{
Laércio da Silva Pereira $^{(\mathbb{D}}$, Everaldo Moreira da Silva $^{2 *}{ }^{(0)}$, Julian Junio de Jesus Lacerda ${ }^{2}$, \\ Rafael Felippe Ratke ${ }^{3(0)}$, Carlos José Gonçalves de Souza Lima $\left.{ }^{4}{ }^{(}\right)$, Theuldes Oldenrique da Silva Santos ${ }^{(\bullet}$ \\ 'São Paulo State University, Botucatu, Brazil \\ ${ }^{2}$ Federal University of Piauí, Bom Jesus, Brazil \\ ${ }^{3}$ Federal University of Mato Grosso do Sul, Chapadão do Sul, Brazil \\ ${ }^{4}$ Federal University of Piauí, Teresina, Brazil \\ *Corresponding author, e-mail: everaldo@ufpi.edu.br
}

\begin{abstract}
Water and nitrogen availability are fundamental for obtaining a high yield of the watermelon plant. However, the appropriate levels of irrigation and nitrogen to be applied according to specific cultivation conditions should be previously determined. The objective of the present study was to evaluate the effects of irrigation and nitrogen levels in fertigation on the phytotechnical parameters and yield of the Top Gun hybrid watermelon plant. The experiment was conducted at São Luiz Ranch, in Bom Jesus (PI), from August 4 to October 15, 2015. The blocks in strips experimental design was used with four repetitions, and the treatments consisted of five irrigation depths $(114.17,156.86,221.16,268.87$, and $317.09 \mathrm{~mm})$ and five doses of nitrogen in fertigation $(0,50$, 100,150 , and $\left.200 \mathrm{~kg} \mathrm{ha}^{-1}\right)$. The growth rate of the main and primary branches, leaf area, specific leaf area, stem diameter, dry mass of the aerial part, number of fruits, and commercial production per plant were evaluated. Both hydric and nutritional stress caused decreased growth rates, leaf areas, and specific leaf areas, and the highest growth expressions were found with the combination of a $317.09 \mathrm{~mm}$ irrigation depth and $200 \mathrm{~kg} \mathrm{ha}^{-1}$ nitrogen. The irrigation depths did not influence the diameter of the stem nor the accumulation of dry mass. Nitrogen doses did not influence the number of fruits and production. The $247.95 \mathrm{~mm}$ irrigation depth promoted the highest commercial fruit production of the watermelon plant.
\end{abstract}

Keywords: Citrullus lanatus, water deficit, irrigation depth, fertigation

\section{Introduction}

The watermelon crop has worldwide distribution; it occurs mainly in tropical regions, grown both in irrigated and dry agriculture systems (Morais et al., 2008). Although the use of irrigation can maximize crop yield, adequate control of the irrigation depth is required for specific crop and farming conditions. According to Najafabadi et al. (2018), the water requirement of the watermelon crop is of $400-600 \mathrm{~mm}$.

Studies developed by Morais et al. (2008), Melo et al. (2010), and Özmen et al. (2015) have showed the beneficial effects of adequate soil water availability on the parameters of growth, physiology, efficiency, and yield of the watermelon plant. Melo et al. (2010) found that the maximum leaf area growth and main branch growth rate were obtained with the application of the $204 \mathrm{~mm}$ irrigation depth. Özmen et al. (2015) found the highest yield per plant of $16.90 \mathrm{~kg}$ plant with an irrigation depth of $464.90 \mathrm{~mm}$.

Another way to maximize growth, yield, and water use efficiency in agricultural crops is through the application of nitrogen $(N)$ fertilizers. $N$ is one of the macronutrients that actively participates in the synthesis of the chlorophyll molecule, contributes to vegetative growth, improves the quality of harvested fruits, and can also mitigate the effects caused by water stress (Badr et al., 2016; Sheshbahreh et al., 2019), in addition to promoting economic benefits. However, excessive dosage applications can increase the osmotic potential of the soil solution and consequently reduce water absorption.

By evaluating the effects of conventional $\mathrm{N}$ fertilization on watermelon cultivation, Araújo et al. (2011), Barros et al. (2012), and Nowaki et al. (2017) found that the maximum yield of watermelon was obtained with applications of $144.70,114.76$, and $187 \mathrm{~kg} \mathrm{ha}^{-1}$ of $\mathrm{N}$, 
respectively. However, Morais et al. (2008) found that the highest fruit yield was obtained with $421 \mathrm{~mm}$ of water and $267 \mathrm{~kg} \mathrm{ha}^{-1}$ of $\mathrm{N}$ applied in a conventional way. The use of the fertigation technique can reduce the amounts of $\mathrm{N}$ applied, improve the efficiency of use of this nutrient, as well as maximize the growth and fruit yield of the watermelon plant.

Edaphoclimatic conditions influence variations in crop water and nutrient consumption. Therefore, periodic studies are required to estimate the water and $\mathrm{N}$ demand for each specific crop condition. In view of the above, the objective of the present study was to evaluate the effects of irrigation depths and $\mathrm{N}$ levels in fertigation on phytotechnical parameters and yield of the watermelon plant.

\section{Material and Methods}

The experiment was conducted at São Luiz Ranch $\left(9^{\circ} 05^{\prime} 20,4^{\prime \prime} \mathrm{S}, 44^{\circ} 20^{\prime} 55,1^{\prime \prime} \mathrm{W}\right.$; altitude of $283 \mathrm{~m}$ ) in the municipality of Bom Jesus, Piauí, in an area of 2,500 $\mathrm{m}^{2}$, in August-October 2015. The climate at this region is dry sub-humid with an average annual rainfall of 900 $1200 \mathrm{~mm}$ and an average temperature of $26.5^{\circ} \mathrm{C}$, but temperatures of $40^{\circ} \mathrm{C}$ are common during the year.

The soil at the experimental area is classified as Fluvial Neosol, with free sand and sand textural classes in the 0.0-0.20 and 0.20-0.40 m layers, respectively. The soil was prepared by plowing and grading, and by chemical analysis; liming was calculated by the base saturation method, which was used to raise the saturation to $60 \%$ and correct acidity. Dolomitic limestone with Relative
Power of Total Neutralization (RPTN) of $94 \%$ was applied to a dosage of $1.05 \mathrm{Mg} \mathrm{ha-}^{-1}$ and incorporated at a depth of $0.20 \mathrm{~m}$. After 30 days of correction, the soil had the chemical, physical, and water attributes shown in Table 1.

The experimental design adopted was of blocks in strips with four repetitions. Treatments corresponded to the application of five irrigation depths $(50,75,100,125$, and $150 \%$ of the reference evapotranspiration) and five doses of $\mathrm{N}$ in fertigation $\left(0,50,100,150\right.$, and $200 \mathrm{~kg} \mathrm{ha}^{-1}$ of $\mathrm{N}$ ) in the watermelon plant crops. The useful area of each experimental plot was occupied by five plants, totaling $20 \mathrm{~m}^{2}$

Seeds of the Top Gun hybrid were used because of its growing acceptance in the market and lack of technical information in the region. The planting was performed by direct sowing in the field, in pits of $0.3 \times 0.3$ $\times 0.3 \mathrm{~m}$ (width $\times$ length $\times$ depth) and with one seed per pit (2.00 $\times 2.00 \mathrm{~m}$ space for each seed).

Phosphate and potassium fertilization were performed based on the soil chemical analysis (Table 1) and following the fertilization and liming recommendations for the State of Ceará (Aquino et al., 1993). The following quantities and sources were used: $120 \mathrm{~kg} \mathrm{ha}^{-1}$ of simple superphosphate locally distributed in each pit 10 days before planting; and $120 \mathrm{~kg} \mathrm{ha-}{ }^{-1}$ of potassium chloride distributed according to the rate of application of this nutrient for the crop (Table 2). The localized drip irrigation system consisted of: 3 hp pump with $8.5 \mathrm{~m}^{3} \mathrm{~h}^{-1}$ flow, 3,500 rpm rotation, and $70 \%$ yield; disk filter; ducts, main piping, and $50 \mathrm{~mm}$ nominal diameter (ND) PVC piping lines measuring 10,50 , and $3 \mathrm{~m}$ respectively. The secondary

Table 1. Chemical, physical, and water attributes of the soil in the experimental area in Bom Jesus, PI, Brazil.

\begin{tabular}{|c|c|c|}
\hline \multirow{2}{*}{$\begin{array}{l}\text { Attributes } \\
\text { Chemicals }\end{array}$} & \multicolumn{2}{|c|}{ Layer (m) } \\
\hline & $0.0-0.20$ & $0.20-0.40$ \\
\hline $\mathrm{pH}\left(\mathrm{CaCl}_{2}\right)$ & 5.3 & 5.0 \\
\hline$P(m e l) ~ m g ~ d m-3$ & 4.3 & 2.4 \\
\hline $\mathrm{K}\left(\mathrm{mg} \mathrm{dm}-^{3}\right)$ & 53.0 & 30.0 \\
\hline $\mathrm{Ca}\left(\mathrm{cmol}_{\mathrm{c}} \mathrm{dm}-{ }^{3}\right)$ & 2.1 & 1.5 \\
\hline $\mathrm{Mg}\left(\mathrm{cmol}_{\mathrm{c}} \mathrm{dm}^{3}\right)$ & 1.2 & 0.9 \\
\hline$S\left(m g ~ d m-{ }^{3}\right)$ & 3.4 & 4.0 \\
\hline $\mathrm{Al}$ (replaceable) $\left(\mathrm{cmol}_{\mathrm{c}} \mathrm{dm}-{ }^{3}\right)$ & 0.2 & 0.3 \\
\hline $\mathrm{Na}\left(\mathrm{mg} \mathrm{dm}-^{3}\right)$ & 6.0 & 5.0 \\
\hline$M . O\left(g ~ d m-{ }^{3}\right)$ & 11.0 & 7.0 \\
\hline \multicolumn{3}{|l|}{ Physical } \\
\hline Coarse sand $\left(\mathrm{g} \mathrm{kg}^{-1}\right)$ & 628.8 & 656.8 \\
\hline Fine Sand ( $\left.\mathrm{g} \mathrm{kg}^{-1}\right)$ & 266.5 & 245.5 \\
\hline Silt $\left(g \mathrm{~kg}^{-1}\right)$ & 42.0 & 31.3 \\
\hline Clay (g kg-1) & 62.6 & 66.0 \\
\hline Particle density $\left(\mathrm{g} \mathrm{cm}^{3}{ }^{3}\right)$ & 2.86 & 2.70 \\
\hline Soil density $\left(\mathrm{g} \mathrm{cm}^{-3}\right)$ & 1.61 & 1.64 \\
\hline \multicolumn{3}{|l|}{ Water } \\
\hline FC (\%, by volume) & 16.9 & 13.2 \\
\hline PWP (\%, by volume) & 4.0 & 4.5 \\
\hline
\end{tabular}


lines of the system consisted of: PVC pipes of ND $32 \mathrm{~mm}$ from which the side lines of polyethylene of $16 \mathrm{~mm}$ of ND measuring $52 \mathrm{~m}$ came out, with idrop drippers online equispaced by $2.0 \mathrm{~m}$ with unit flow rate of $8 \mathrm{~L} \mathrm{~h}^{-1}$, service pressure of 1 bar, and discharge coefficient of the flowpressure curve "x" equal to 0.5.

The water used for irrigation came from a well drilled at a depth of $150 \mathrm{~m}$ and was stored in a tank $(3.0 \times 6.0 \times 2.0 \mathrm{~m}$; width $\times$ length $\times$ depth $)$ with a total capacity of $36 \mathrm{~m}^{3}$. The water had the following physical and chemical characteristics: $\mathrm{CE}=30.22 \mu \mathrm{S} / \mathrm{cm} ; \mathrm{pH}=5.1$; $\mathrm{Ca}=1.0, \mathrm{Mg}=0.6 ; \mathrm{K}=0.4 ; \mathrm{Na}=3.9 ; \mathrm{Cl}=4.5 ; \mathrm{CHO}^{3}=3.4$ (in $\mathrm{mg} \mathrm{L}^{-1}$ ). The water was classified as excellent quality for irrigation purposes $\left(\mathrm{C}_{1} \mathrm{~S}_{1}\right)$.

The applied irrigation depths were calculated based on reference evapotranspiration (ETo) obtained through the Penman-Monteith method and adapted by FAO (Allen et al., 2006). The following values of crop coefficients $(\mathrm{KC})$ obtained by Ferreira (2010) were used: 0.44 for phase I (1-12 days), 0.97 phase II (13-32 days), 1.51 phase III (33-64 days), and 1.28 (65-73 days) for phase IV. The methodology proposed by Keller \& Bliesner (1990) was used to determine the reduction coefficients
$\left(K_{L}\right)$ by localized irrigation for each irrigation depth.

Daily climatic data (Figure 1) were obtained from an automatic meteorological station of the National Institute of Meteorology (INMET), installed at the Federal University of Piauí (UFPI) in Bom Jesus, at the Campus Prof ${ }^{a}$ Cinobelina Elvas - CPCE, which is located $1000 \mathrm{~m}$ from the experimental area. This station comprised air temperature, relative air humidity, solar radiation, and wind speed sensors, with which ETo was calculated daily. As wind speed can only be obtained at a height of $10 \mathrm{~m}$ in the meteorological stations of INMET, the conversion to a height of $2 \mathrm{~m}$ was performed following the equation proposed by Allen et al. (2006). The variations of the irrigation depths started and finished at 20 days and 53 days after the emergency, respectively.

$\mathrm{N}$ fertigation (urea form) was performed daily throughout the cycle, established from the march of application of this nutrient to the crop (Table 2) (Andrade Júnior et al., 2007). The solutions were injected into the irrigation system using a venturi type injector with an application rate of $80 \mathrm{Lh}^{-1}$ and a working pressure of 1 bar.
(A)

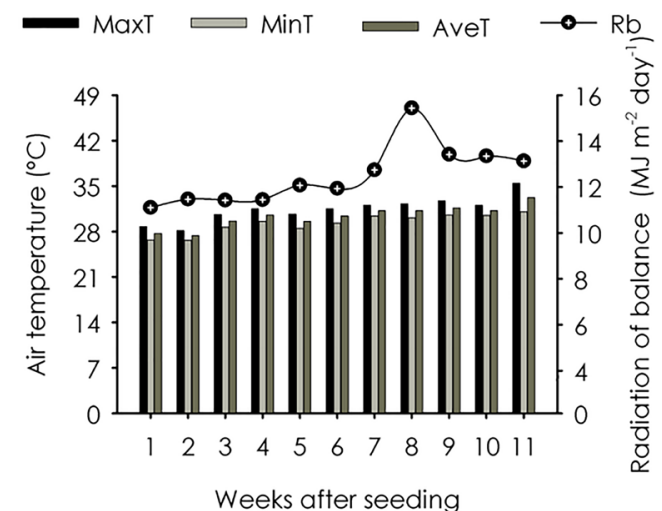

(B)

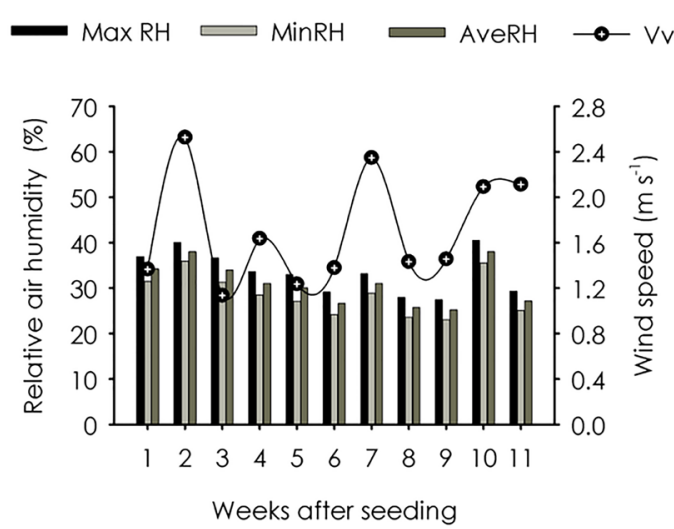

Figure 1. Weekly averages during the trial period (2015) in Bom Jesus (PI) of maximum, minimum, and average air temperatures and radiation balance (A); and of maximum, minimum, and average relative air humidity and wind speed (B).

Table 2. Nitrogen and potassium application march used for watermelon plant.

\begin{tabular}{|c|c|c|c|c|c|c|c|c|}
\hline \multirow[t]{2}{*}{ Nutrient } & \multicolumn{8}{|c|}{ Days after emergency (DAE) } \\
\hline & $1-13$ & $14-20$ & $21-27$ & $28-34$ & $35-41$ & $42-48$ & $49-55$ & Total \\
\hline $\mathrm{K}_{2} \mathrm{O}$ & $5 \%$ & $5 \%$ & $8 \%$ & $16 \%$ & $18 \%$ & $23 \%$ & $25 \%$ & $100 \%$ \\
\hline $\mathrm{N}$ & $6 \%$ & $7 \%$ & $15 \%$ & $27 \%$ & $30 \%$ & $10 \%$ & $5 \%$ & $100 \%$ \\
\hline $\mathrm{N}\left(\mathrm{kg} \mathrm{ha}^{-1}\right)$ & \multicolumn{8}{|c|}{ N applied (g plant) } \\
\hline 0 & 0.0 & 0.0 & 0.0 & 0.0 & 0.0 & 0.0 & 0.0 & 0 \\
\hline 50 & 1.2 & 1.4 & 3.0 & 5.4 & 6.0 & 2.0 & 1.0 & 20 \\
\hline 100 & 2.4 & 2.8 & 6.0 & 10.8 & 12.0 & 4.0 & 2.0 & 40 \\
\hline 150 & 3.6 & 4.2 & 9.0 & 16.2 & 18.0 & 6.0 & 3.0 & 60 \\
\hline 200 & 4.8 & 5.6 & 12.0 & 21.6 & 24.0 & 8.0 & 4.0 & 80 \\
\hline
\end{tabular}


Foliar applications of calcium $\left(6.0 \%, 79.8 \mathrm{~g} \mathrm{~L}^{-1}\right)$, magnesium $\left(2.0 \%, 26.60 \mathrm{~g} \mathrm{~L}^{-1}\right)$, and boron $(1.0 \%, 13.33$ $\left.\mathrm{g} \mathrm{L}^{-1}\right)$ were performed through the Liqui-plex source at an interval of 7 days from the 33rd day after sowing (beginning of flowering) to 66 days after sowing. Weed control was carried out through weeding and pest and disease management in a preventive manner with weekly applications of products recommended for the production of the watermelon plant.

The fruit was harvested at 73 days after sowing. Point of harvest was identified based on the drying of the tendril closest to the fruit and on the change in fruit color especially in the region in direct contact with the soil, which changed from white to light yellow (Araújo et al., 2011). The morphophysiological variables were quantified based on the growth rate of the main branch (GRMB, $m$ day $^{-1}$ ) and the growth rate of the primary branch (GRPB, $m$ day $^{-1}$ ), which was measured from the largest primary branch issued by the plant. Growth rate assessments were performed by weekly readings from the 10th after seedling emergence (Melo et al., 2010). The stem diameter $(\mathrm{SD}, \mathrm{Cm})$ and leaf area $\left(\mathrm{LA}, \mathrm{m}^{2}\right)$ of the plants were determined at 72 days after sowing using a digital pachymeter and benchtop leaf area integrator model LI-3100C, respectively.

At the end of the crop cycle, two plants from each plot were collected and dried in a forced circulation greenhouse at $65^{\circ} \mathrm{C}$ until they reached a constant mass to obtain the accumulation of dry biomass from the aerial part (g plant) (Ferraz et al., 2011). The specific leaf area (SLA, $\mathrm{cm}^{2} \mathrm{~g}^{-1}$ ) was calculated by the ratio of LA to dry leaf mass (Ferraz et al., 2011; Ramos Júnior et al., 2013).

The number of commercial fruits per plant was calculated as the number of commercial fruits in each plot divided by the number of plants in the plot. Finally, the commercial production of fruit per plant (kg plant) was determined by the ratio of the total mass of commercial fruit in the plot to the number of plants. Fruits classified as commercial were those free from mechanical damage, phytosanitary problems, stains, and deformations, and with a mass of $10 \mathrm{~kg}$ or more.

The data were submitted to a variance analysis at a $5 \%$ significance level. In case of isolated significant effect among the factors, a quantitative analysis of polynomial regression was performed by testing the linear and quadratic models. For the variables that presented a significant interaction effect, analysis of response surfaces was performed. The models used were chosen based on the significance of the regression coefficients, at the level, of $5 \%$ significance, and the highest value of the determination coefficient $\left(R^{2}\right)$.

\section{Results and Discussion}

Hot and dry weather conditions resulting from dry air and the high amount of energy available as solar radiation (Figure 1) predominated during the crop cycle favoring the occurrence of high evapotranspiration demand (Figure 2). In these conditions, the increase in wind speed promoted an increase in evapotranspiration; small variations in wind speed may result in significant variations in the evapotranspiration process (Allen et al., 2006).

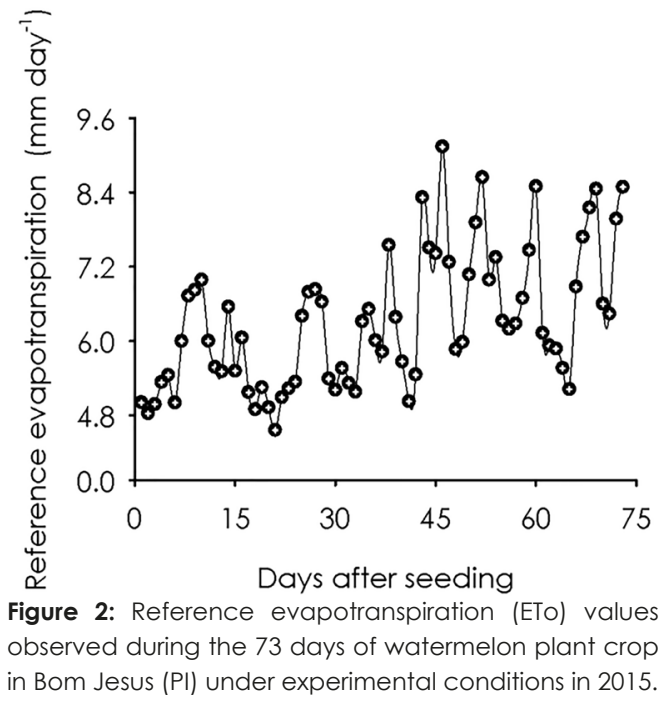

In the present study, ETo was of $4.5-9.13 \mathrm{~mm}$ (mean $=6.3 \mathrm{~mm} \mathrm{day}^{-1}$ ) and above $6.5 \mathrm{~mm}$ on approximately $51 \%$ of the cultivation days; values of $5-7 \mathrm{~mm}$ day $^{-1}$ are typically considered high (Allen et al., 2006). During the experimental period, there was no occurrence of rainfall; therefore, all responses in crop growth and yield related to water availability occurred only because of the variation in the irrigation depths applied.

The irrigation depths for the treatments of 50, 75, 100,125 , and $150 \%$ of ETo corresponded to the application of $114.17,156.86,221.16,268.87$, and $317.09 \mathrm{~mm}$ cycles, respectively. These results are close to the $100-300 \mathrm{~mm}$ irrigation range applied by Melo et al. (2010), Ferreira et al. (2013), Ferreira et al. (2015), and Abdelkhalik et al. (2019). However, they are below the water requirement of the watermelon plant described by Najafabadi et al. (2018) of $400-600 \mathrm{~mm}$. The variations observed in the water requirement of the watermelon plant may be justified by variations in climate, soil, cultural management, and the cycle of cultivars.

When analyzing GRMB and GRPB, a significant effect of the interaction $(p<0.01)$ among the factors was noted. Maximum expressions in the growth of 0.114 
and $0.101 \mathrm{~m} \mathrm{day}^{-1}$, respectively, were found in the combination of $317.09 \mathrm{~mm}$ of water and $200 \mathrm{~kg} \mathrm{ha}^{-1}$ of $\mathrm{N}$ (Figure 3). For the GRMB, N was evidently the most limiting

(A)

$G R M B=0.0683+0.0000931 " N+0.0000861 " W R^{2}=0.80$

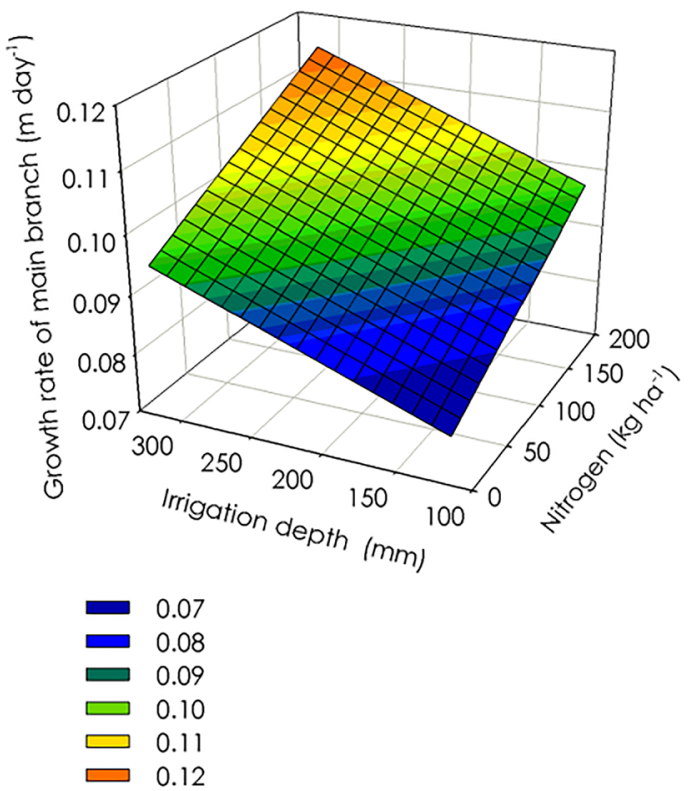

factor, contrary to what was observed in GRPB, for which the irrigation depth was more limiting, indicated by the greater slope for this factor in the response surface.

(B)

$G R P B=0.0564+0.0000648 " N+0.000100 " W R^{2}=0.81$

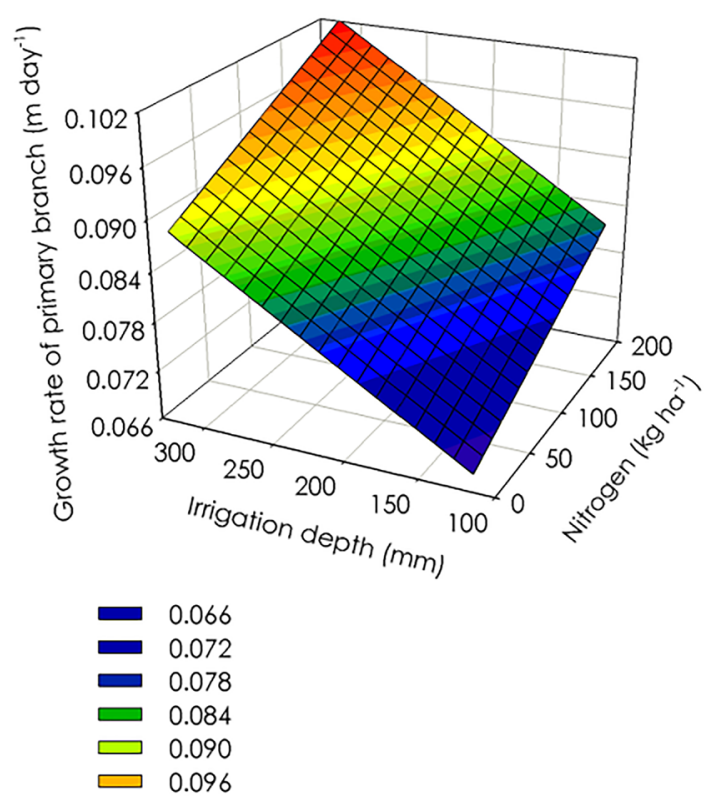

Figure 3. Response surfaces of the main branch (A) and primary branch (B) growth rates of the watermelon plant as a function of irrigation depths and nitrogen doses in fertigation. ${ }^{* *}$ significant to $1 \%$ significance by Student's $\dagger$ test.

In the present study, we found lower growth rates in plants that received 114.17- and $156.86 \mathrm{~mm}$ irrigation depth combined with 0 and $50 \mathrm{~kg} \mathrm{ha}^{-1}$ doses of $\mathrm{N}$. These results can be attributed to the soil water deficit, which causes a reduced contact of $\mathrm{N}$ ions $\left(\mathrm{NO}_{3}-\right.$ and $\left.\mathrm{NH}^{4+}\right)$ from the soil solution with the root system because $\mathrm{N}$ is absorbed by mass flow; this in turn causes decreased plant growth (Wang et al., 2017), cell elongation by decreasing the water flow of the xylem, and increase of stomatal closure, which reduces the photosynthetic rate (Hu et al., 2010; Zhang et al., 2013) and consequently decreases growth rates.

The elongation of branches in watermelon plants implies gains in LA, improving the photosynthetic capacity of the plant, and this elongation is influenced by the amount of water available in the soil (Melo et al., 2010). Water deficiency virtually affects all aspects of growth, including anatomical, morphological, physiological, and biochemical modifications of crops (Talbi et al., 2015). This occurs especially in olericultural crops such as the watermelon plant, which are more susceptible to water deficit, especially with large variations in soil water levels, resulting in reduced vegetative growth (Melo et al., 2010; Mo et al., 2015; Abdelkhalik et al., 2019).

The watermelon plants that expressed the highest growth rates of main and primary branches had earlier and more abundant flowering, corroborating the observations of Melo et al. (2010); these authors found the maximum growth rate of $0.132 \mathrm{~m} \mathrm{day}^{-1}$ for the main branch of the Crimson Sweet cultivar with the use of an irrigation depth of $143.33 \mathrm{~mm}$.

As well as the growth rates of branches, LA was also influenced by the significant interaction between the factors $(p<0.05)$. LA was found to increase as irrigation and $\mathrm{N}$ levels in fertigation increased. The analysis of the response surface showed that the $317.09 \mathrm{~mm}$ irrigation depth, together with the application of $200 \mathrm{~kg} \mathrm{ha}^{-1}$ of $\mathrm{N}$, was responsible for the highest LA value $\left(2.24 \mathrm{~m}^{2}\right.$ ) (Figure 4A).

The greater availability of water and $\mathrm{N}$ in the soil favored the greater growth of the main branch and of primary and secondary branches (Figure 3), allowing a greater development in number and size of leaves, maximizing the gain in LA (Figure 4A). According to Morais et al. (2008), the foliar expansion rate and its contribution to the photosynthetic process are related to the vegetative growth velocity, and a higher LA results in improvements in the production of photoassimilates. The lower LA observed in water and $\mathrm{N}$ deficit conditions is possibly characterized as a mechanism of adaptation of the plant to both hydric and nutritional stress. In cucurbits such as the watermelon plant, the increase in $\mathrm{N}$ dose 
stimulates growth and an increase in LA (Antunes et al., 2014).

In the present study, LA $\left(2.24 \mathrm{~m}^{2}\right)$ was greater than that observed by Melo et al. (2010) for the Crimson Sweet cultivar $\left(1.831 \mathrm{~m}^{2}\right)$ with a water volume of 197.2 $\mathrm{mm}$. It can be inferred that the variations in LA are related to the applied irrigation depth, a form of fertilizer

(A)

\section{$L A=0.5952+0.0065^{\prime \prime} N+0.0011 " W R^{2}=0.94$}

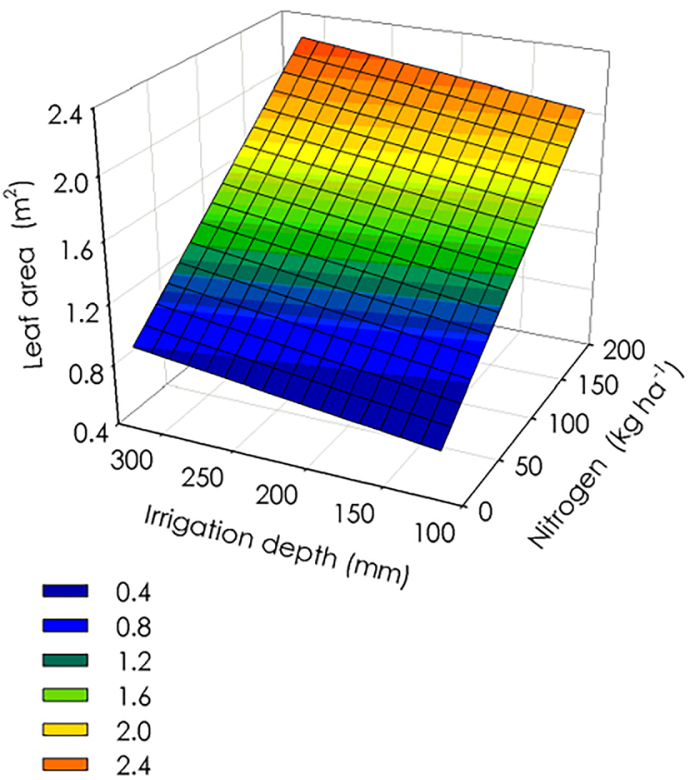

application, as well as to irrigation management and local edaphoclimatic conditions. Moreover, in the present study, the plants emitted small leaves and in lower intensity under water and $\mathrm{N}$ deficit conditions; this is in accordance with Wang et al. (2017) and Najafabadi et al. (2018), who also found a decrease in the LA of the watermelon plant under water deficit conditions.

(B)

\section{$S L A=45.5076+0.3077^{* *} \mathrm{~N}+0.0694^{* *} \mathrm{~W} \quad R^{2}=0.75$}

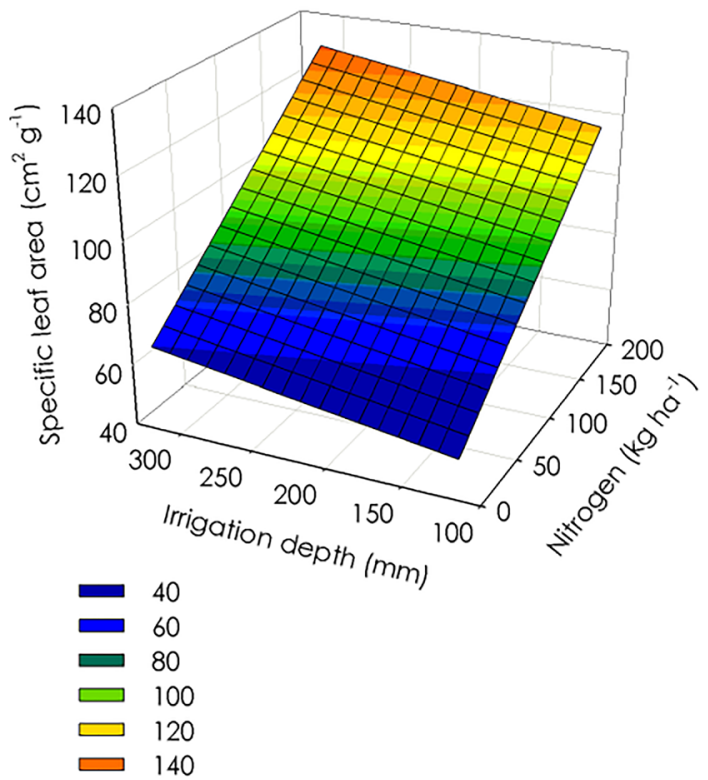

figure 4. Response surfaces of leaf area (A) and specific leaf area (B) of the watermelon plant resulting from the irrigation depths and nitrogen doses in fertigation. ${ }^{* *}$ significant to $1 \%$ significance by Student's $\dagger$ test.

The response of SLA is the result of the variations that occur in the LA and the accumulation of biomass in the aerial part. The foliar area is a morphophysiological component of a plant species, whereas biomass is an anatomical component of a plant species as it is related to the internal composition (number and size) of mesophyll cells, and the inverse of SLA reflects the thickness of the leaves (Ferraz et al., 2011). In this study, it was found that the SLA of the watermelon plant was significantly influenced by the interaction between the factors $(p<0.05)$. The analysis of the response surface for SLA showed that the watermelon plants that received $317.09 \mathrm{~mm}$ of water and $200 \mathrm{~kg} \mathrm{ha}^{-1}$ of $\mathrm{N}$ showed the highest results of $129.05 \mathrm{~cm}^{2} \mathrm{~g}^{-1}$ (Figure 4B). The SLA showed similar behavior to the LA, with lower means observed under water and $\mathrm{N}$ deficit conditions in the soil. The decrease in SLA with increased water stress was also observed in other crops such as melon (Ferraz et al., 2011) and in cover plants such as black oats, millet, graniferous sorghum, and guinea sorghum (Ramos Júnior et al., 2013). Based on these results, it can be inferred that plants that grew under both hydric and nutritional stress had greater leaf thickness as a form of adaptation to stress. The increase of SLA in the higher levels of water and $\mathrm{N}$ probably contributed to reducing the resistance of the leaf mesophyll to $\mathrm{CO}_{2}$ flow, favoring the achievement of higher photosynthetic rates.

Stem diameter (SD) and dry mass accumulation of the aerial part (DMAP) were influenced only by the application of $\mathrm{N}$ doses in fertigation $(p<0.01)$. The data of both variables were adjusted to the quadratic polynomial regression model (Figure 5A and B). Quadratic regression response to dry biomass levels of watermelon plants in function of $\mathrm{N}$ dose application was also reported by Araújo et al. (2011). From the derivations of the adjusted equations, the estimated maximums of $17.76 \mathrm{~mm}$ and $262.74 \mathrm{~g}$ per plant were obtained with the applications of 114.08 and $124.63 \mathrm{~kg} \mathrm{ha}^{-1}$ of $\mathrm{N}$, respectively.

In this study, increments of $23.08 \%$ and $22.71 \%$ of SD and DMAP, respectively, were found for the treatment without $\mathrm{N}$ application; this is attributed to the $\mathrm{N}$ deficiency in this treatment, which causes decreased vegetative growth and less accumulation of dry biomass from the aerial part. $\mathrm{N}$ is essential for growth as it participates in 
the synthesis of important $\mathrm{N}$ compounds such as proteins, chlorophyll, and DNA (Ishida \& Makino, 2018) favoring

(A)
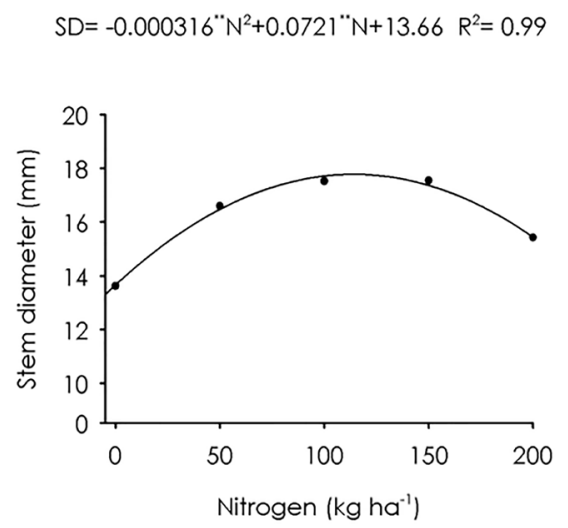

(C)

$\mathrm{NFPP}=0.002447^{* *} \mathrm{~W}+0.904 R^{2}=0.90$

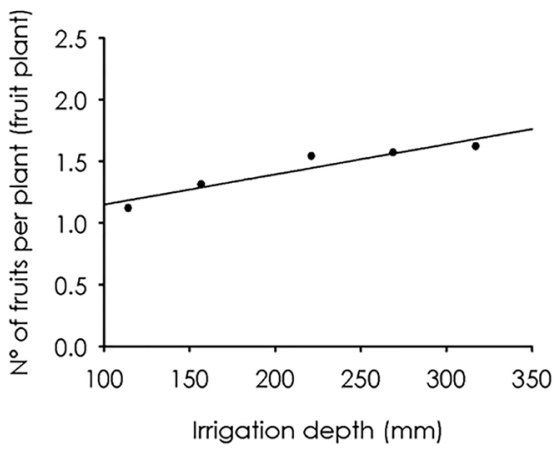

growth, development, and accumulation of plant biomass (Yang et al., 2013).

(B)

DMAP $=-0.003842 * N^{2}+0.9577 \ddot{N}+203.06 R^{2}=0.87$

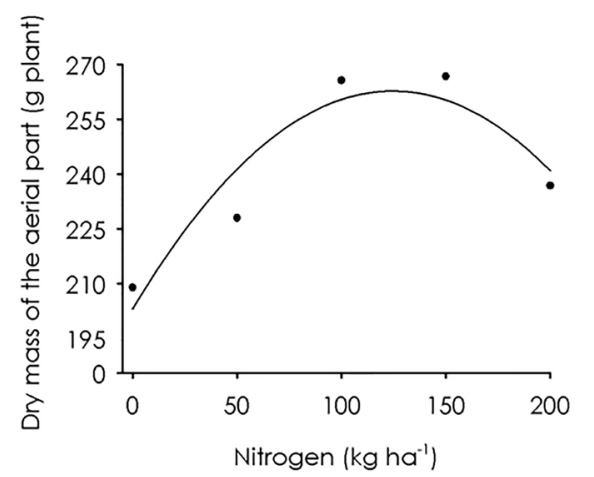

(D)

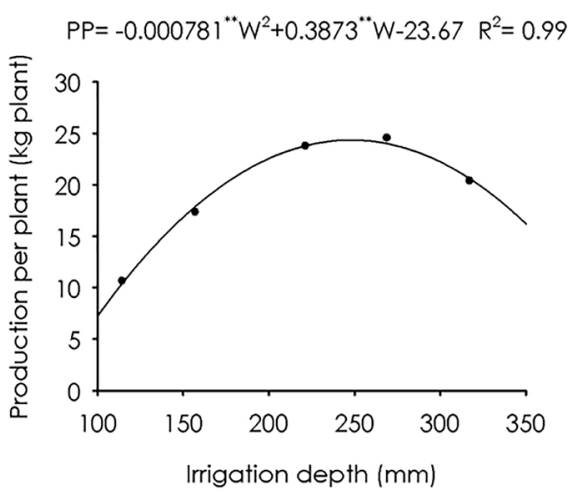

Figure 5. Regression for stem diameter (A) and dry mass accumulation of the aerial part (B) of the watermelon plant in function of nitrogen doses in fertigation; the average number of commercial fruits (C) and commercial production per plant (D) in function of irrigation depths. ${ }^{* *}$ significant to $1 \%$ significance by Student's t test.

Under low $\mathrm{N}$ quantities in the soil, as is the case with the treatment of $50 \mathrm{~kg} \mathrm{ha}^{-1}$ of $\mathrm{N}$, the plants did not fully express their genetic potential. In this condition, a series of morphological and physiological changes occur that negatively affect the growth and partition of assimilated $\mathrm{N}$ between the source organs and drains (Pereira Filho et al., 2014). The increase in DMAP can be inferred to have also resulted from gain in LA; however, the severe attacks of Didymella and Mildew at the end of the crop cycle, mainly in the treatment of $200 \mathrm{~kg} \mathrm{ha}^{-1} \mathrm{~N}$, affected the accumulation of dry biomass and caused decreases in this treatment.

The irrigation depths influenced the number of commercial fruits per plant $(p<0.05)$. The data of this variable notably adjusted to the growing linear regression model, with a maximum of 1.67 fruits per plant at 317.09 $\mathrm{mm}$ of water (Figure $5 \mathrm{C}$ ). This result is justified by the high growth rates and LA gain that occurred in this irrigation treatment, increasing the production of photoassimilates and consequently, the number of fruits per plant. The study developed by Abdelkhalik et al. (2019) also pointed to a reduction in the number of fruits of the watermelon plant with an increase in water deficit. However, Özmen et al. (2015) evaluated the effects of irrigation depths on watermelon plants and found no significant difference in treatments regarding the number of fruits per plant.

Agricultural crop yields are affected by both water and soil nutrient availability. In the present work, a response of the commercial fruit production of the watermelon plant to $\mathrm{N}$ fertigation was expected; however, this did not occur. Maize, beans, and soya cultivations in previous years, as well as levels of organic matter, plant debris, and leaching of nutrients such as $\mathrm{N}$ itself, likely contributed to the lack of response in fruit production of the watermelon plant to $\mathrm{N}$ fertigation.

The results of the present study show that only the irrigation depths influenced the commercial production per plant (PP) of the watermelon plant $(p<0.01)$. The estimated maximum of $24.34 \mathrm{~kg}$ per plant was obtained with the application of $247.95 \mathrm{~mm}$ of water, with a decrease in yield from this point (Figure 5D). The increase in vegetative growth rates, LA, SLA, and the number of 
commercial fruits observed in the $317.09 \mathrm{~mm}$ irrigation depth did not reflect in significant gains in the commercial production of the crop, which can be attributed to an increased competition in photoassimilate translocation resulting from the increased number of fruits (Figure $5 \mathrm{C}$ ). This increase, however, promoted a decrease in the mass of commercial fruit, resulting in fruit outside the trade pattern required by the domestic market.

The decrease in PP after the $247.95 \mathrm{~mm}$ irrigation level probably resulted from nutrient leaching to deeper soil layers. In non-excessively acidic sandy soils with low cation exchange capacity and low water retention capacity, as is the case of the Neosol used in this study (Table 1), the use of high irrigation depths favors the leaching of nutrients from the root region of the crop (Campelo et al., 2014; Nowaki et al., 2017).

In this study, the lowest yields per plant were found with the irrigation depths of 114.17 and $156.86 \mathrm{~mm}$. These results are in line with those reported by Özmen et al. (2015), Najafabadi et al. (2018), and Abdelkhalik ef al. (2019), who also observed lower yields of watermelon fruits under water deficit conditions.

\section{Conclusions}

The phytotechnical parameters of the watermelon crop were negatively affected by water and $\mathrm{N}$ deficiency in the soil. The $317.09 \mathrm{~mm}$ irrigation depth combined with the application of $200 \mathrm{~kg} \mathrm{ha}^{-1}$ of $\mathrm{N}$ favors the growth and development of the crop but hinders PP. The maximum commercial production is obtained with the $247.95 \mathrm{~mm}$ irrigation depth.

\section{References}

Abdelkhalikab, A., Pascual- Sevaac, N., Nájerad, I. Ginerd, A., Baixaulid, C., Pascual, B. 2019. Yield response of seedless watermelon to different drip irrigation strategies under Mediterranean conditions. Agricultural Water Management 212: 99-110.

Allen, R.G., Pereira, L.S., Raes, D., Smith, M. 2006. Evapotranspiración del cultivo: guia para la determinacion de los requerimientos de agua de los cultivos. Irrigation and Drainage Paper, Rome, Italy. 322 p.

Andrade Júnior, A.S., Dias, N.S., Figueredo Junior, L.G.M., Daniel, R. 2007. Frequência de aplicação de nitrogênio e de potássio via água de irrigação por gotejamento na cultura da Melancia em Parnaíba, PI. Agropecuária Científica no Semi-Árido 03: 01-07.

Antunes, G., Ferreira, A.P.S., Puiatti, M., Cecon, P.R., Silva, G.C.C. 2014. Produtividade e qualidade de frutos de pepino africano em resposta à adubação nitrogenada. Revista Ceres 61: 141-146.

Aquino, A.B., Aquino, B.F., Ferreyra Hernandez, F.F., Holanda, F.J.M., Freire, J.M., Crisóstomo, L.A., Costa, R.I.,
Uchôa, S.C.P., Fernandes, V.L.B. 1993. Recomendações de adubação e calagem para o Estado do Ceará. Editora da UFC, Fortaleza, Brasil. 247p.

Araújo, W.F, Barros, M.M., Medeiros, R.D., Chagas, E.A., Neves, L.T.B.C. 2011. Crescimento e produção de melancia submetida a doses de Nitrogênio. Revista Caatinga 24: 80-85.

Badr, M.A., Abou-Hussein, S.D., El-Tohamy, W.A. 2016. Tomato yield, nitrogen uptake and water use efficiency as affected by planting geometry and level of nitrogen in an arid region. Agricultural Water Management 169: 90-97.

Barros, M.M., Araújo, W.F., Neves, L.T.B.C., Campos, A.J., Tosin, J.M. 2012. Produção e qualidade da melancia submetida a adubação nitrogenada. Revista brasileira de engenharia agrícola e ambiental 16: 1078-1084.

Campelo, A.R., Azevedo, B.M., Nascimento Neto, J.R., Viana, T.V.A., Pinheiro Neto, L.G., Lima, R.H. 2014. Manejo da cultura do melão submetida a frequências de irrigação e fertirrigação com nitrogênio. Horticultura Brasileira 32: 138-144.

Ferraz, R.L.S., Melo, A.S., Ferreira, R.S., Dutra, A.F., Figueredo, L.F. 2011. Aspectos morfofisiológicos, rendimento e eficiência no uso da água do meloeiro "Gália" em ambiente protegido. Revista Ciência Agronômica 42: 957-964.

Ferreira, J.O.P. 2010. Evapotranspiração e coeficientes de cultura da melancieira irrigada por gotejamento em Alvorada do Gurguéia-PI. 121 p. (D.Sc. Thesis) - São Paulo State University, Jaboticabal, Brazil.

Ferreira, J.O.P., Pavani, L.C., Bastos, E.A. 2013. Coeficientes de cultura para a melancieira irrigada por gotejamento no Vale do Gurgueia, PI. Irriga 18: 509-521.

Ferreira, V. M., Klar, A. E., Andrade Junior, A. S., Bastos, E. A., Oliveira, S. R. M. 2015. Evapotranspiração e coeficiente de cultura da melancia na microrregião de Teresina, Pl, Brasil. Comunicata Scientiae 6: 488-494.

Hu, L.X., Wang, Z.L., Huang, B.R. 2010. Diffusion limitations and metabolic factors associated with inhibition and recovery of photosynthesis from drought stress in a C-3 perennial grass species. Physiologia Plantarum 139: 93106.

Ishida, H., Makino, A. 2018. Impacts of autophagy on nitrogen use efficiency in Plants. Soil Science and Plant Nutrition 64: 100-105.

Keller, J., Bliesner, R.D. 1990. Sprinkle and trickle irrigation. Van Nostrand Reinhold, New York, USA. 625 p.

Melo, A.S., Suassuna, J.F., Fernandes, P.D., Brito, M.E.B., Suassuna, A.F., Aguiar Netto, A.O. 2010. Crescimento vegetativo, resistência estomática, eficiência fotossintética e rendimento do fruto da melancieira em diferentes níveis de água. Acta Scientiarum. Agronomy 32: 73-79.

Mo, Y., Yang, R., Liu, L., Gu, X., Yang, X., Wang, Y., Zhang, 
X., Li, H. 2015. Growth, photosynthesis and adaptive responses of wild and domesticated watermelon genotypes to drought stress and subsequent re-watering. Plant Growth Regulation 77: 229-241.

Morais, N.B., Bezerra, F.M.L., Medeiros, J.F., Chaves, S.W.P. 2008. Resposta de plantas de melancia cultivadas sob diferentes níveis de água e de nitrogênio. Revista Ciência Agronômica 39: 369-377.

Najafabadi, M.Y., Soltani, F., Noory, H., Díaz-Pérez, J.C. 2018. Growth, yield and enzyme activity response of watermelon accessions exposed to Irrigation water déficit. International Journal of Vegetable Science 24: 323-337.

Nowaki, R.H.D., Cecílio Filho, A.B., Faria. R.T., Wamser, A.F., Cortez, J.W.M. 2017. Effect of nitrogen fertilization on yield and quality of watermelon, cv. Top Gun. Revista Caatinga 30: 164-171.

Özmen, S., Kanber, R., Sarı, N., Ünlü, M. 2015. The effects of deficit irrigation on nitrogen consumption, yield, and quality in drip irrigated grafted and ungrafted watermelon. Journal of Integrative Agriculture 14: 966-976.

Pereira Filho, J.V., Bezerra, F.M.L., Silva, A.R.A., Sousa, C.C.M., Castro, J.M. 2014. Frequência de irrigação e aplicação de nitrogênio em meloeiro irrigado por gotejamento nas condições semiáridas do Nordeste. Científica 42: 11-22.

Ramos Junior, E.U., Machado, R.A.F., Olibone, D., Castoldi, G., Ramos, B.M. 2013. Crescimento de plantas de cobertura sob déficit hídrico. Semina: Ciências Agrárias 34: 47-56.

Sheshbahreh, M.J., Dehnavi, M.M.,Salehi, A., Bahreininejad, B. 2019. Effect of irrigation regimes and nitrogen sources on biomass production, water and nitrogen use efficiency and nutrients uptake in coneflower (Echinacea purpurea L.). Agricultural Water Management 213: 358-367.

Talbi, S., Puertas, M.C.R., Hernández, A., Terrón, L. Ferchichi, A., Sandalio, L.M. 2015. Drought tolerance in a Saharian plant Oudneya africana: role of antioxidant defences. Environmental and Experimental Botany 111: 114-126.

Wang, S., Callaway, R.M., Zhou, D.W., Weiner, J. 2017. Experience of inundation or drought alters the responses of plants to subsequent water conditions. Journal of Ecology 105: 176-187.

Yang, Y., Lu, X., Yan, B., Li, B., Sun, J., Guo, S., Tezuka, T. 2013. Bottle gourd rootstock-grafting affects nitrogen metabolism in $\mathrm{NaCl}$-stressed watermelon leaves and enhances short-term salt tolerance. Journal of Plant Physiology 170: 653-661.

Zhang, L., Zhang, L., Sun, J., Zhang, Z., Ren, H., Sui, X. 2013. Rubisco gene expression and photosynthetic characteristics of cucumber seedlings in response to water deficit. Scientia Horticulturae 161: 81-87.
Conflict of Interest Statement: The authors declare that the research was conducted in the absence of any commercial or financial relationships that could be construed as a potential conflict of interest.

All the contents of this journal, except where otherwise noted, is licensed under a Creative Commons Attribution License attribuition-type BY. 